\title{
Improving the indoor air quality (IAQ) in naturally ventilated lecture hall with a single facade by solar chimneys
}

\author{
Ahmed Fikry ${ }^{\top}$ and Asmaa Elsayed ${ }^{2 *}$
}

\author{
* Correspondence: asmaa. \\ elshoura83@gmail.com \\ ${ }^{2}$ Architecture Department, Giza \\ Higher Institute of Engineering and \\ Technology, Giza, Egypt \\ Full list of author information is \\ available at the end of the article
}

\begin{abstract}
In this paper, the indoor air pollution was investigated inside an educational building which contains air pollutants with elevated concentrations. A field study was conducted in a naturally ventilated, single-faceted lecture's hall to evaluate the indoor air quality (IAQ). Both air velocity and carbon dioxide $\left(\mathrm{CO}_{2}\right)$ concentrations were measured at the respiratory area level to compare these values with ASHRAE standard (62.01-2019). The computational fluid dynamics (CFD) 3D model was utilized to predict the air velocity, and $\mathrm{CO}_{2}$ concentrations, and to validate the measured air concentrations. The measured results fairly agree with the numerical CFD data with a $6.2 \%$ difference between both values. This paper deals with experimental work to study the effect of the cross-section area, the number, and the height of the solar chimneys. The results showed that using solar chimneys improved the natural ventilation in the hall and minimized the $\mathrm{CO}_{2}$ concentrations. Additionally, using the chimney cross-section area of $0.25^{*} 0.25 \mathrm{~m}, 0.30^{*} 0.30 \mathrm{~m}$, and $0.40^{*} 0.40$ to $0.50^{*} 0.50 \mathrm{~m}$ can reduce the $\mathrm{CO}_{2}$ concentrations to $(3 \%, 6.2 \%, 6.4 \%$, and $6.7 \%$, respectively). While using three chimneys instead of only one, the ventilation flow rate increased from 61 to $70.9 \%$. The effect of the height of the chimney on the average of $\mathrm{CO}_{2}$ concentrations inside the hall was examined. The modeled height rates $(1,3,5$, and $7 \mathrm{~m}$, respectively) were improved to $26 \%, 33.6 \%$, and $48.7 \%$, respectively.
\end{abstract}

Keywords: Indoor air quality, Natural ventilation, Carbon dioxide $\left(\mathrm{CO}_{2}\right)$, Computational fluid dynamics (CFD), Lecture hall, Solar chimney

\section{Introduction}

Indoor air pollution is one of the most important environmental threats to public health worldwide, given the increase in the number of indoor air quality diseases. Previous studies have found that the concentration of indoor pollutants is two to five times higher than in the outdoor environment, which in some cases, is reaching 100 times higher than the concentration of outdoor pollutants. Most people spend between 80 to $90 \%$ of their lives indoors; therefore the indoor air quality has a significant impact on public health [1-3].

(c) The Author(s). 2021 Open Access This article is licensed under a Creative Commons Attribution 4.0 International License, which permits use, sharing, adaptation, distribution and reproduction in any medium or format, as long as you give appropriate credit to the original author(s) and the source, provide a link to the Creative Commons licence, and indicate if changes were made. The images or other third party material in this article are included in the article's Creative Commons licence, unless indicated otherwise in a credit line to the material. If material is not included in the article's Creative Commons licence and your intended use is not permitted by statutory regulation or exceeds the permitted use, you will need to obtain permission directly from the copyright holder. To view a copy of this licence, visit http://creativecommons.org/licenses/by/4.0/. The Creative Commons Public Domain Dedication waiver (http://creativecommons.org/publicdomain/zero/1.0/) applies to the data made available in this article, unless otherwise stated in a credit line to the data. 
The IAQ in classrooms should be considered carefully, especially in the third world countries, where most classes are ventilated naturally. In some classrooms, natural ventilation is a requirement for the design of a low-energy consuming building $[4,5]$.

Cairo city, Egypt, has high concentrations of atmospheric pollutants including particulate matter $(\mathrm{PM})$, carbon monoxide $(\mathrm{CO})$, carbon dioxide $\left(\mathrm{CO}_{2}\right)$, and nitrogen oxides $\left(\mathrm{NO}_{\mathrm{x}}\right)[6,7]$. Transport and distribution of air pollutants generally depend on the ventilation system [6,7]. Some studies of naturally ventilated university classrooms have shown that the measured levels exceed the recommended value of $1000 \mathrm{ppm}$ [8]. The main objective of ventilating indoor environments is to provide a comfortable and healthy environment for students [9]. The main goal herein is to provide fresh and pleasant indoor air without any negative impact on health taking into account energy efficiency and sustainability [9].

In comparison to K-12 schools, the research studies that focused on IAQ in higher education buildings were limited [10,11]. The effect of IAQ and ventilation rates on performance and health using psychological tests was investigated [12]. It is reported that carbon dioxide was the most influencing pollutant to be considered when calculating the outdoor air supply rates $[9,12]$.

The use of solar chimneys improved the air movement in buildings with natural ventilation using the sun's renewable and clean energy [13]. Egypt has an average daily solar energy of $4.9 \mathrm{kWh} / \mathrm{m}^{2}$ [13]. These climatic features encourage the application of solar chimneys to provide comfortable conditions in educational buildings [14].

Previous studies have examined the solar chimneys by their potential advantages in terms of energy requirements [15]. A steady-state mathematical model was developed based on the thermal network approach to predict natural induced ventilation using passive solar flues [16]. Some studies focused on the number and height of solar chimneys, air gap width (e.g., cross-sectional area), and direction of the chimney to natural ventilation in space [17]. It is reported that using 1, 2, or 3 solar chimneys can reduce temperature to $6 \%, 10 \%$, and $12 \%$, respectively. Also using 2 and 3 chimneys instead of 1 increased the ventilation flow rate to $13 \%$ and $33 \%$, respectively [17]. The study found that the speed in a living area is achieved by using a solar chimney with a height of $1.85 \mathrm{~m}$, a width of $2.65 \mathrm{~m}$, an angle of inclination of 75 degrees, and an air gap of 0.28 $\mathrm{m}$ [18]. Results showed that the natural ventilation was improved by using multiple solar energy chimneys [18]. It is reported that the use of solar chimneys increased the air exchange in the classroom and reduced the levels of $\mathrm{CO}_{2}$ concentration $[17,19]$.

The application of computational fluid dynamics (CFD) has widely investigated the IAQ role in the classrooms [20, 21]. Awbi and Gan [20] used CFD modeling to make predictions of air movement and thermal comfort in a mechanically well-ventilated office unit [20]. The CFD can be used to predict airflow and thermal comfort in offices with natural and mechanical ventilation with same accuracy [22]. The CFD was used to predict the airflow pattern in an air-conditioned seminar room [23]. Despite the abovementioned studies, there are little studies focused on the use of CFD simulation in the lecture's hall particularly with natural ventilation [24].

This paper aims to evaluate the naturally ventilated lecture's hall and verify if the standard IAQ values recommended by ASHRAE standards [25] are applied and satisfied. The novelty of this work is conducting IAQ in a large-size lecture's hall (dimensions: $12.55 \mathrm{~m} * 19 \mathrm{~m} * 4 \mathrm{~m}$; full capacity and critical case: 300 students) located in a 
square with high traffic density in relation to small internal halls that used in other similar studies. The CFD model was used to simulate the IAQ standards in a lecture's hall at Faculty of Engineering at Cairo University, Egypt. The measured data were compared with the experimental modeled data and also to those of similar studies. In addition, the solar chimney was chosen to improve the rate of ventilation inside the lecture's hall to reduce its $\mathrm{CO}_{2}$ concentrations until it reaches the acceptable concentration ratios.

\section{Methods}

\section{CFD modeling and case study}

This study includes two models: numerical (assumed) and measured (experimental). The initial model of the case study was drawn within 3D AutoCAD (source: https://www.autodesk.com/products/autocad), and then, it was exported into the ANSYS CFD model [26]. The selected lecture's hall at the Faculty of Engineering, Cairo University, contains 110 students with dimensions of $\left(12.55 \mathrm{~m}^{*} 19 \mathrm{~m} * 4 \mathrm{~m}\right)$ with $(X, Y, Z)$ Cartesian coordinates. The air ventilation has naturally inlet through single-facade windows. The lecture's hall has 12 sliding windows, each of which has a dimension of $0.675 \mathrm{~m}^{*} 1.45 \mathrm{~m}$ and the total ventilated area was calculated as $11.745 \mathrm{~m}^{2}$. The doors are open during the teaching period, where supplied air was measured from the inlet windows at an average velocity of $0.4 \mathrm{~m} / \mathrm{s}$. Figure 1 shows the specific features and components of the lecture's hall which is located in the third floor in the north direction (NNW, $15^{\circ}$ ).

\section{Case modeling}

\section{Numerical meshing}

In this study, meshes with various sizes were used and it was found that small and dense sizes delivered more accurate results (Table 1). The mesh used in this study was very dense more relative to the contaminant sources and then gradually increased till it reached to the reasonable internal size of elements to the whole volume. To do this, a size function was generated with a starting size of 0.02 to 0.2 $\mathrm{m}$ of mesh (Table 1).

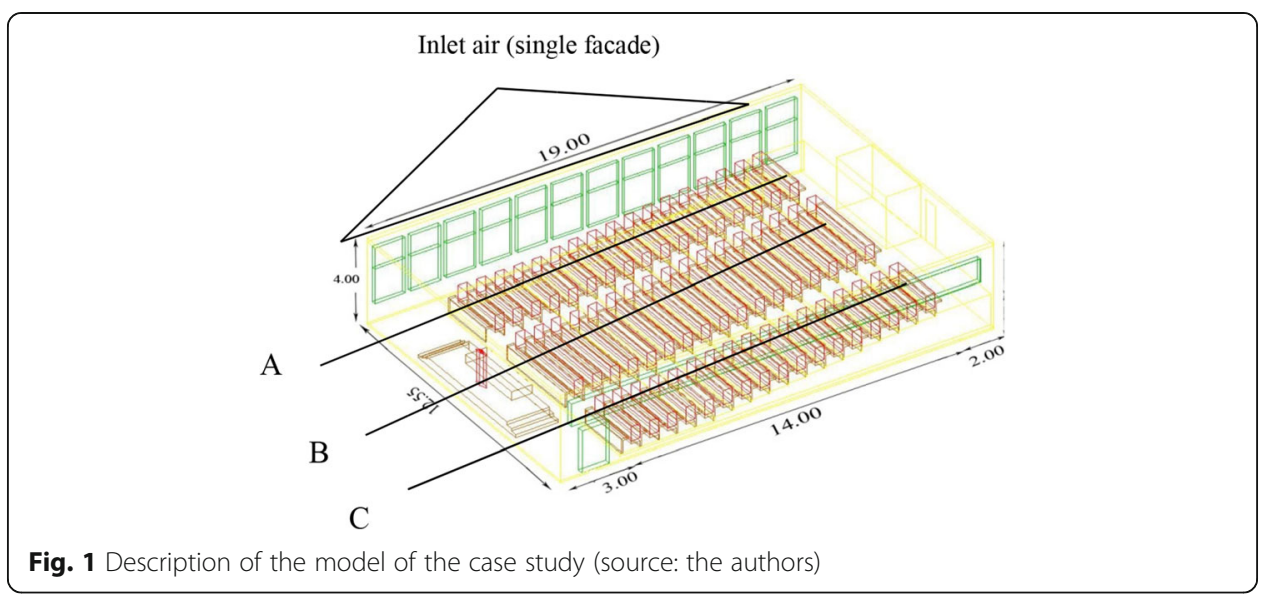


Table 1 The size of mesh

\begin{tabular}{ll}
\hline Mesh & Element size $(\mathbf{m})$ \\
\hline Students face & 0.02 \\
Inlet air & 0.2 \\
Inlet and outlet of the chimney & 0.15 \\
\hline
\end{tabular}

\section{Steady-state boundary conditions (input data)}

In the case study, the air inlet velocity was measured at the inlet flow window with an average value of $0.4 \mathrm{~m} / \mathrm{s}$ and temperature of $27^{\circ} \mathrm{C}$ which was measured in October 2017 because it was the beginning of the semester with a relative humidity of $45 \%$. The measured outdoor $\mathrm{CO}_{2}$ was measured at $490 \mathrm{ppm}$.

The occupants' bodies have a temperature of $37^{\circ} \mathrm{C}$ [27], and with no species diffusion. The faces of the occupants are treated as a species source due to the presence of the $\mathrm{CO}_{2}$ in the expired air of the respiratory system of the occupants [28]. The volume of $0.5 \mathrm{~L}$ is considered as the volume of an average breath per occupant [29], and the volume of the gases in the dry expired air under standard conditions are $74.5 \% \mathrm{~N}_{2}, 15.7 \% \mathrm{O}_{2}, 3.6 \% \mathrm{CO}_{2}$, and $6.2 \% \mathrm{H}_{2} \mathrm{O}$. The mass flow of expired air from the occupants is calculated as $2 * 10^{-4} \mathrm{~kg} / \mathrm{s}$ per occupant based on 20 times per minute during normal activity [28].

\section{Measurement of indoor parameters}

The main indoor measured parameters are $\mathrm{CO}_{2}$ concentration and inlet velocity. The measurement devices (EXTECH portable $\mathrm{CO}_{2}$ meter and Anemometer) were used in this study to measure the $\mathrm{CO}_{2}$ concentrations and wind velocity (Fig. 2) (specifications as reported in Table 2). All measurements were taken to compare the output of the experimental work with the numerical predictions.

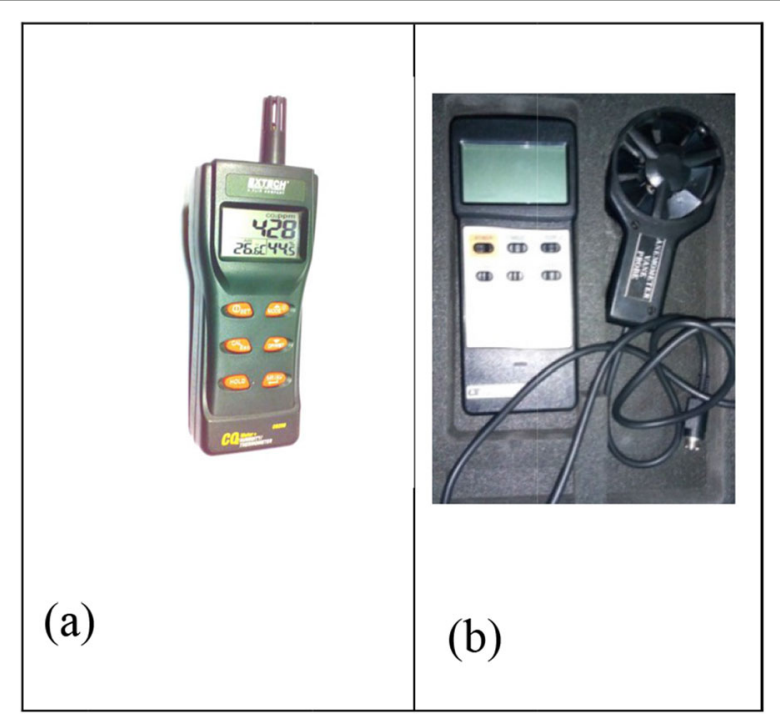

Fig. 2 Measurement devices used EXTECH portable $\mathrm{CO}_{2}$ meter (a) and anemometer (b) (Source: from Environmental lab Cairo university) 
Table 2 Specifications of the devices

\begin{tabular}{|c|c|c|c|c|}
\hline Device & Parameter & Range & Resolution & Accuracy \\
\hline \multirow{4}{*}{$\begin{array}{l}\text { EXTECH O250: Portable IndoorAir Quality } \\
\mathrm{CO}_{2}\end{array}$} & \multirow{2}{*}{$\begin{array}{l}\text { Carbon } \\
\text { Dioxide }\left(\mathrm{CO}_{2}\right)\end{array}$} & $0-5000$ ppm & $1 \mathrm{ppm}$ & $\pm(\% 5 r d g+50 p p m)$ \\
\hline & & $\begin{array}{l}\text { 5000-9999 } \\
\text { ppm }\end{array}$ & $1 \mathrm{ppm}$ & Not specified \\
\hline & Temperature & $\begin{array}{l}14 \text { to } 140^{\circ} \mathrm{F} \\
\left(-10-60^{\circ} \mathrm{C}\right)\end{array}$ & $0.1^{\circ} \mathrm{F} /{ }^{\circ} \mathrm{C}$ & $\pm 0.6^{\circ} \mathrm{C} / 0.9^{\circ} \mathrm{F}$ \\
\hline & Humidity & $0.0-99.9 \%$ & $0.1 \%$ & $\begin{array}{l} \pm 3 \%(10-90 \%) \pm \\
5 \%(<\text { or }>10-90 \%)\end{array}$ \\
\hline \multirow{6}{*}{$\begin{array}{l}\text { Digital anemometer Model AM-4203 Lutron, } \\
\text { ISO- 9001, CE, IEC1010 }\end{array}$} & \multirow[t]{5}{*}{ Air velocity } & $0.4-25.0 \mathrm{~m} / \mathrm{s}$ & $0.1 \mathrm{~m} / \mathrm{s}$ & \multirow[t]{4}{*}{$\pm(2 \%+1 d)$} \\
\hline & & $\begin{array}{l}1.4-90.0 \mathrm{~km} / \\
\mathrm{h}\end{array}$ & $0.1 \mathrm{~km} / \mathrm{h}$ & \\
\hline & & $\begin{array}{l}0.9-55.9 \\
\text { mile/h }\end{array}$ & $0.1 \mathrm{mile} / \mathrm{h}$ & \\
\hline & & $\begin{array}{l}0.8-48.6 \\
\text { knots }\end{array}$ & 0.1 knots & \\
\hline & & $\begin{array}{l}80-4930 \mathrm{ft} / \\
\min \end{array}$ & $1 \mathrm{ft} / \mathrm{min}$ & $\pm(2 \%+20 \mathrm{ft} / \mathrm{min})$. \\
\hline & Temperature & $\begin{array}{l}0-50 / 32 \text { to } \\
122\end{array}$ & $\pm 0.1 / 0.1$ & $\pm 0.8 / 1.5^{\circ} \mathrm{C}^{\circ} \mathrm{F}$ \\
\hline
\end{tabular}

\section{Velocity measurement}

The measuring device used in this study was a hot-wire thermal anemometer (Fig. 2b). The device is based on relating the amount of heat removed by air stream passing on the sensor to the mean velocity of the air stream (Fig. 2b). The air velocity at the windows inlet (with $\mathrm{A}, \mathrm{B}$, and $\mathrm{C}$ sections) was measured at 7 points within the window area (Fig. 3). The average air velocity of the measured 7 points for the case study was $0.4 \mathrm{~m} / \mathrm{s}$.

\section{$\mathrm{CO}_{2}$ measurements}

The indoor $\mathrm{CO}_{2}$ was released in the exhausted air from the students' breathing operation, given that the students are an important source of $\mathrm{CO}_{2}$ inside the lecture's hall

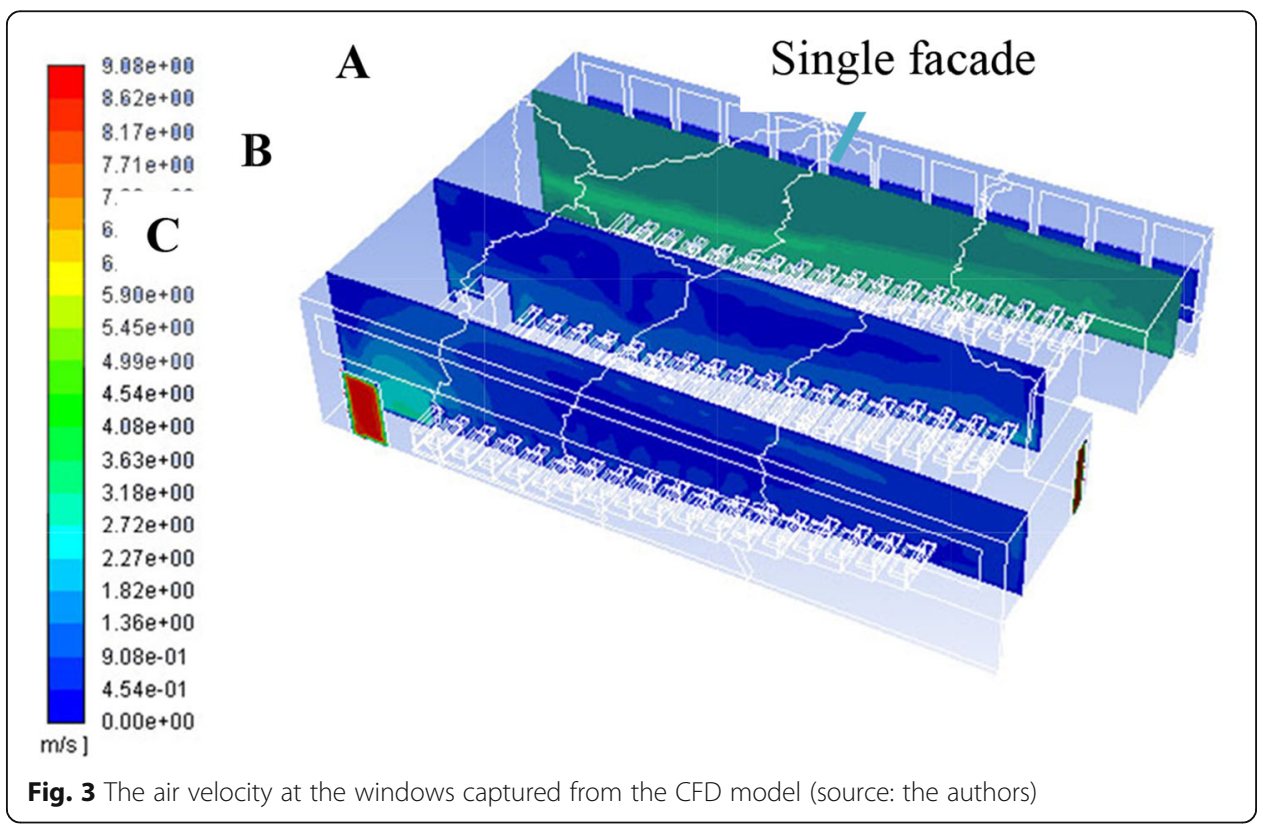




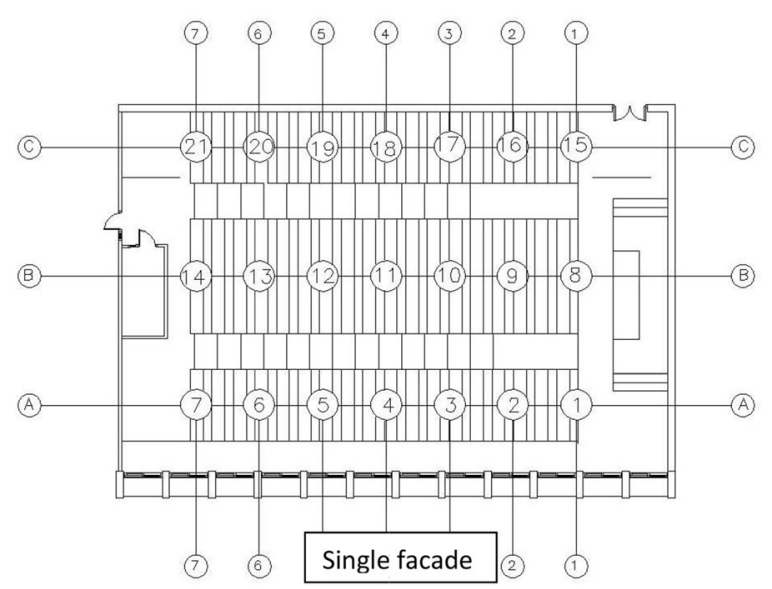

Fig. 4 Measurement 21 points at level 1.20 m breathing zone (source: the authors)

and gave high $\mathrm{CO}_{2}$ levels. The outdoor $\mathrm{CO}_{2}$ measured at $490 \mathrm{ppm}$ due to the high traffic density in the university square in front of the lecture's hall. $\mathrm{CO}_{2}$ is a colorless and odorless gas, with a density of $1.7878 \mathrm{~kg} / \mathrm{m}^{3}$ [28]. $\mathrm{CO}_{2}$ was measured using EXTECH portable $\mathrm{CO}_{2}$ meter, which can store the maximum, minimum, and average values of $\mathrm{CO}_{2}$ (Fig. 2a).

\section{Numerical modeling}

The numerical three-dimensional modeling has been carried out under the assumption of steady-state conditions using ANSYS*2021 R1 Fluent commercial CFD software [26]. The numerical modeling included measurements of air inlet velocity and $\mathrm{CO}_{2}$ at the windows inlet. In addition, $\mathrm{CO}_{2}$ was set at the breathing zone level $(1.20 \mathrm{~m})$ at 21 points as shown in Fig. 4. Multiple field measurements were done in the lecture's hall with various students' density from 9:00 to 16:00 in 3 days (22-24 October 2017 (fall)) and the number of

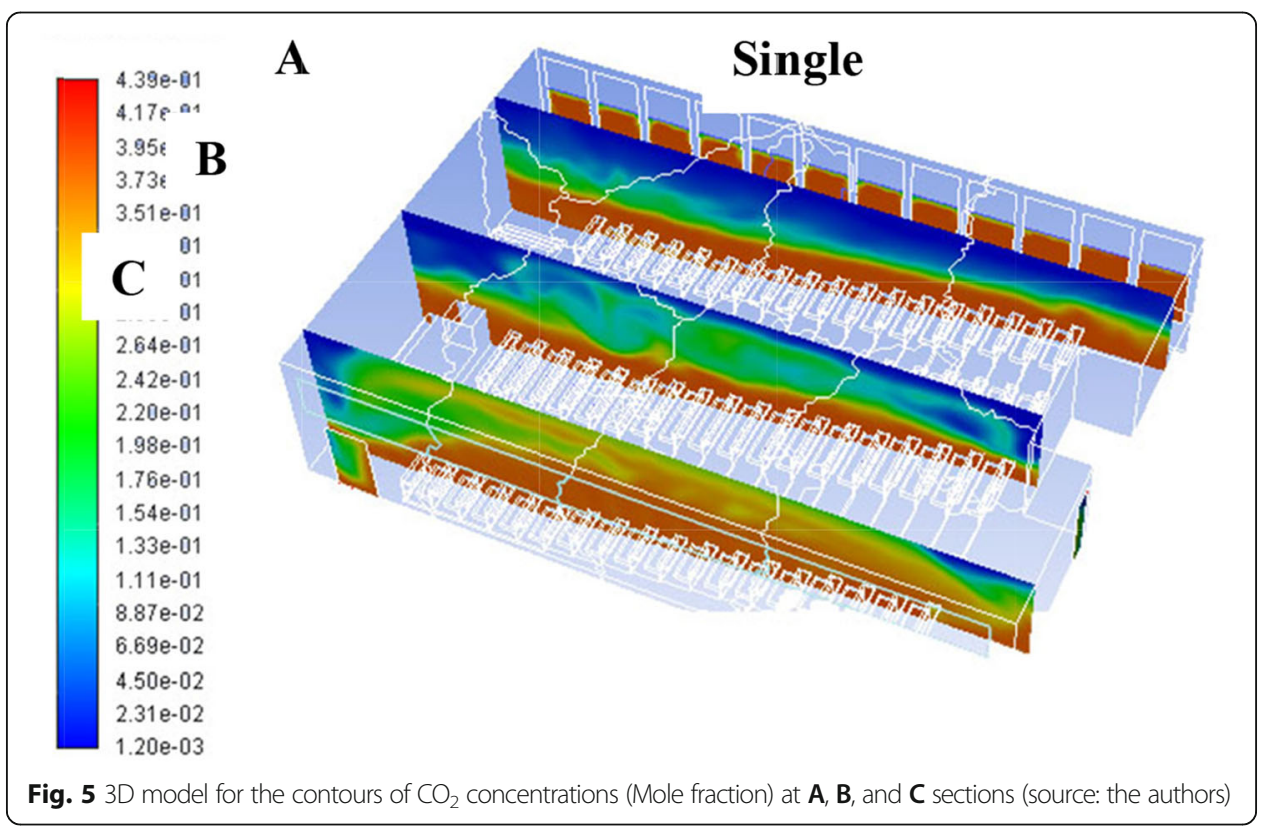




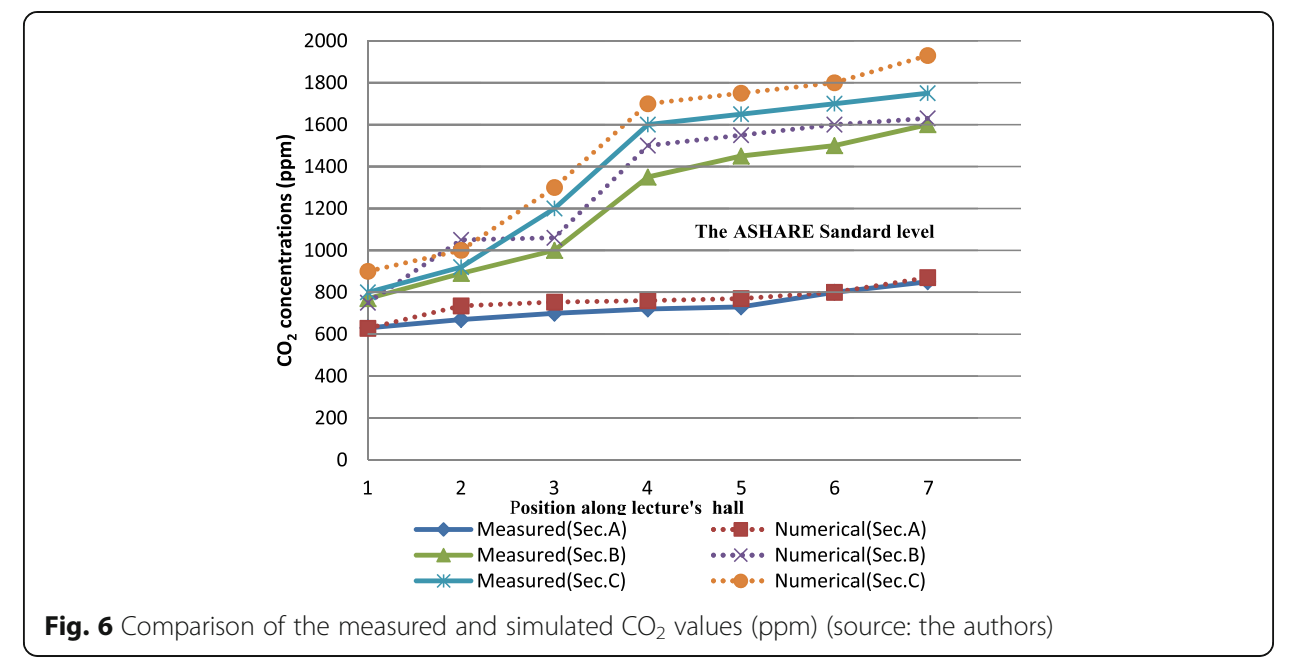

measured occupants were varied from 0 (empty hall), 50, 80, and 110 . However, the study was focused only on the worst case scenario with the maximum capacity (300 occupants) which is delivered from the CFD model. Additionally, the measurements were carried out at different levels with the same direction in the hall to determine the effect of the University's Square and traffic on the air quality in the facility.

\section{Experimental and validation results}

To examine the reliability and accuracy of the CFD model, the RNG $k-\varepsilon$ turbulence model simulation results are compared with the experimental measurements of $\mathrm{CO}_{2}$ (ppm). The computed contours of $\mathrm{CO}_{2}$ concentrations expressed as Mole fraction, which was converted to ppm (PPM equals Mole ${ }^{*} 10^{6}$ ) at the student's breathing level zone as shown in Fig. 5. It is noted that the $\mathrm{CO}_{2}$ concentrations was high at $\mathrm{B}$ and $\mathrm{C}$ areas in the hall except near the inlet window, where the $\mathrm{CO}_{2}$ values were reduced due to the fresh air inlet.

The comparison between the simulated and the measured results are presented in Fig. 6. The $\mathrm{CO}_{2}$ concentrations were plotted for the horizontal plane, specifically at the levels 1 to 7 for sections (A, B, C) values of the horizontal plane (Fig. 6).

It is noted that the measured and simulated values of $\mathrm{CO}_{2}$ in the hall exceed the recommended values by the ASHRAE standard [25] and the Egyptian CODE for ventilation of $1000 \mathrm{ppm}$ [29]. This means that natural ventilation in the lecture hall is not enough, and a ventilation system is needed to maintain the required $\mathrm{CO}_{2}$ concentration levels. The CFD model was validated and the deviation between the numerical and

Table 3 Design variables include the engineering parameters that control the shape of the solar chimney

\begin{tabular}{lll}
\hline No. & Variable types & Variables values \\
\hline 1 & Case one: cross-section square & $\left(0.25^{*} 0.25\right) \mathrm{m},\left(0.3^{*} 0.3\right) \mathrm{m},\left(0.4^{*} 0.4\right) \mathrm{m},\left(0.5^{*} 0.5\right) \mathrm{m}$ \\
2 & Case two: cross-section rectangle & $\left(0.25^{*} 13\right) \mathrm{m},\left(0.3^{*} 13\right) \mathrm{m},\left(0.4^{*} 13\right) \mathrm{m},\left(0.5^{*} 13\right) \mathrm{m}$ \\
3 & Case three: number of chimneys & $(1,3)$ \\
4 & Case four: height & $(1 \mathrm{~m}, 3 \mathrm{~m}, 5 \mathrm{~m}, 7 \mathrm{~m})$ \\
\hline
\end{tabular}




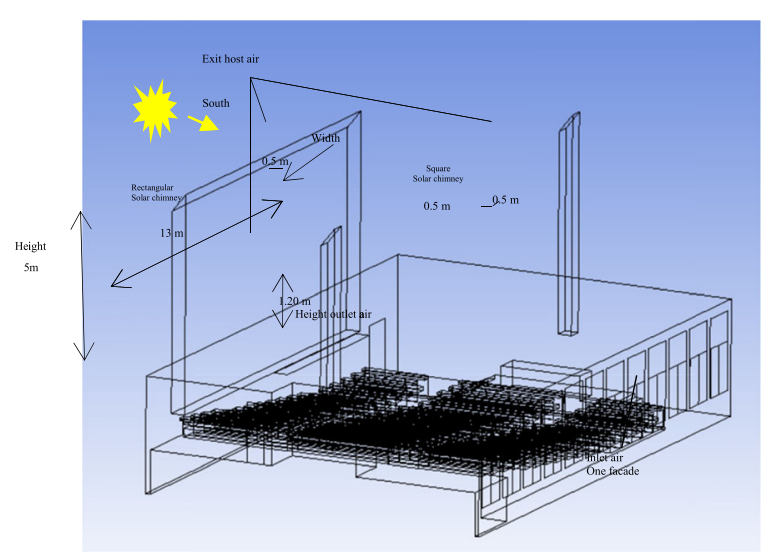

Fig. 7 Schematic diagram of the proposed solar chimney (source: the authors)

experimental results have an average of $6.2 \%$ (Fig. 6), which is in agreement with the average error of [30].

Obviously, the $\mathrm{CO}_{2}$ concentrations in section $\mathrm{A}$ are low, which is referred to the reduction by the fresh air near the inlet window. While, in section $\mathrm{B}$, the $\mathrm{CO}_{2}$ concentrations were higher (Fig. 6), due to lack of air movement. In section $C$, the $\mathrm{CO}_{2}$ values were significantly increased to $1600 \mathrm{ppm}$, which exceeds the ASHRAE standard [25]. This can be referred to the far location of the measured point and the lack of air movement inside the lecture's hall.

Accordingly, the conditions of single facade of the studied hall with number of students (110), at time (10 A.M.) and under natural ventilation are not sufficient and

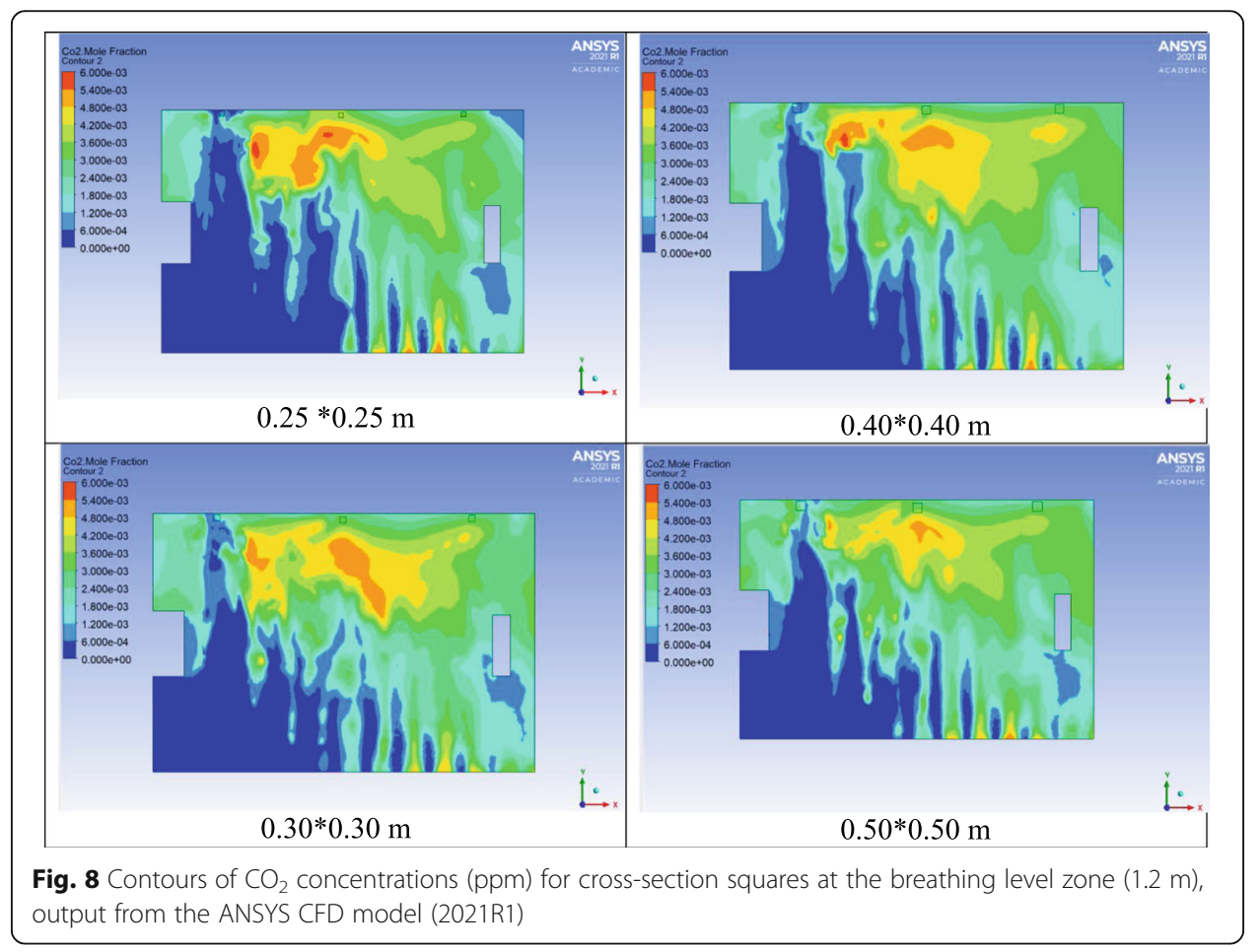




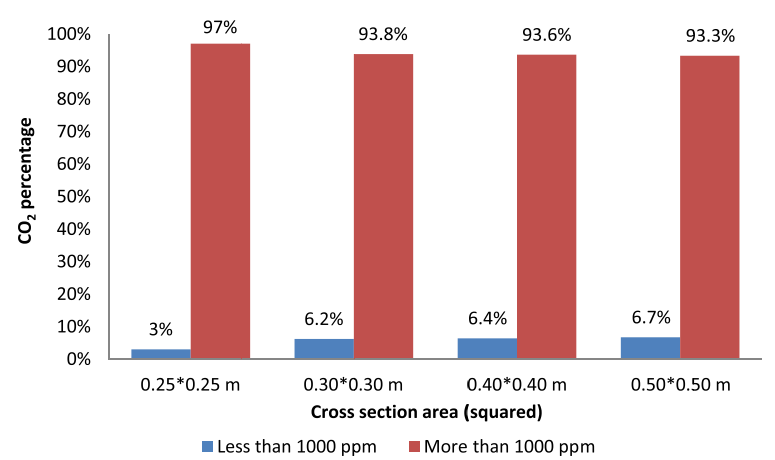

Fig. 9 Percentage of both critical and comfort area to the total area of the tested zone concerning $\mathrm{CO}_{2}$ concentrations (ppm) for the cross-section squares at the breathing level zone (1.2 m) (source: the authors)

requests extra techniques for air movement to reach the acceptable levels of $\mathrm{CO}_{2}$ concentration according to the ASHRAE standards [25].

\section{Proposed natural ventilation retrofitting technique}

Several techniques for retrofitting natural indoor ventilation have been proposed to improve the IAQ $[5,7,13]$. The solar chimney is a better ecofriendly alternative to improve the building ventilation and particularly for the single facade [31]. The proposed technique increases the ventilation performance of the indoor environment using passive solar air heating [17].

In this study, a mathematical model was developed for the solar chimney to determine the optimum design solutions that can achieve the standard ventilation rate [14]. Improvements in the performance of a solar chimney largely depend on the design variables [16]. The relevant design variables such as the engineering parameters controlling the shape of the solar chimney are reported in Table 3 and Fig. 7. The work is carried out on

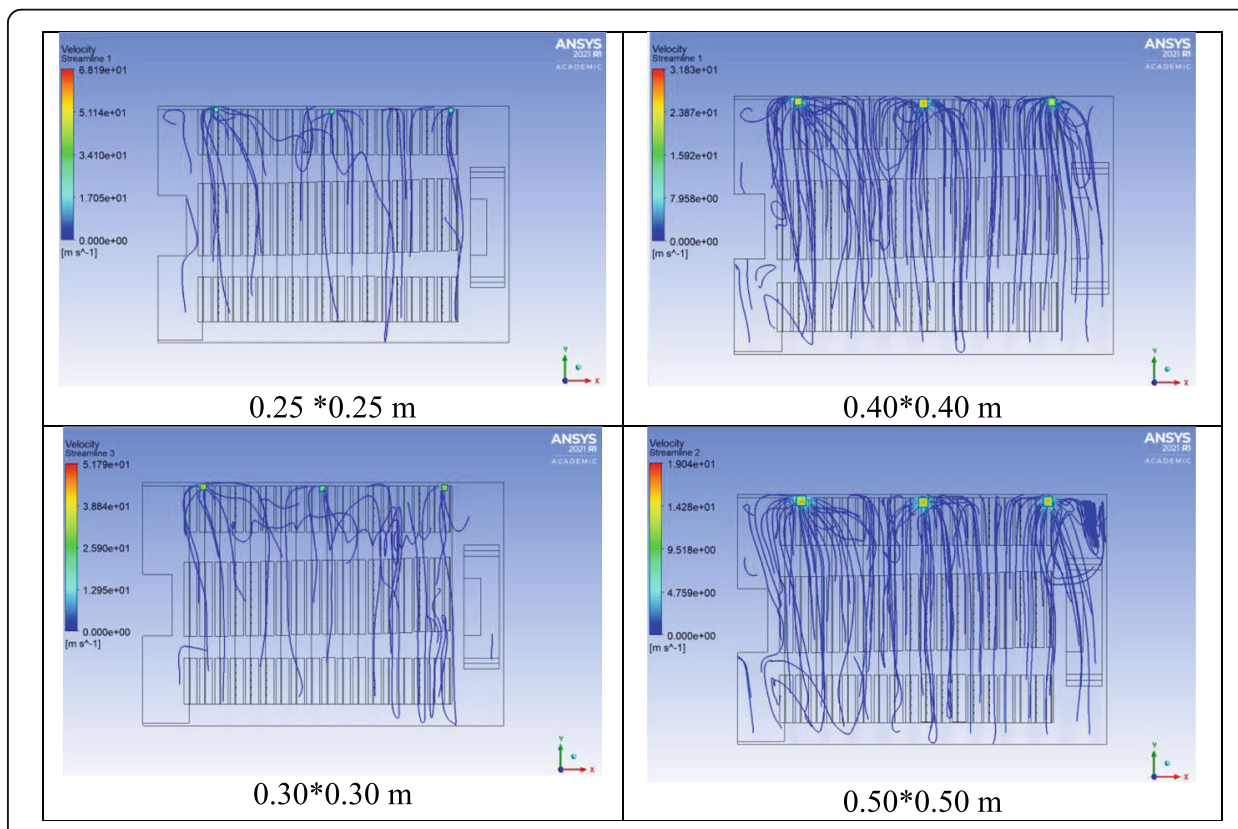

Fig. 10 Stream line air velocity for cross-section square at the breathing level zone (1.2 $\mathrm{m})$, output from the ANSYS CFD model (2021R1) 


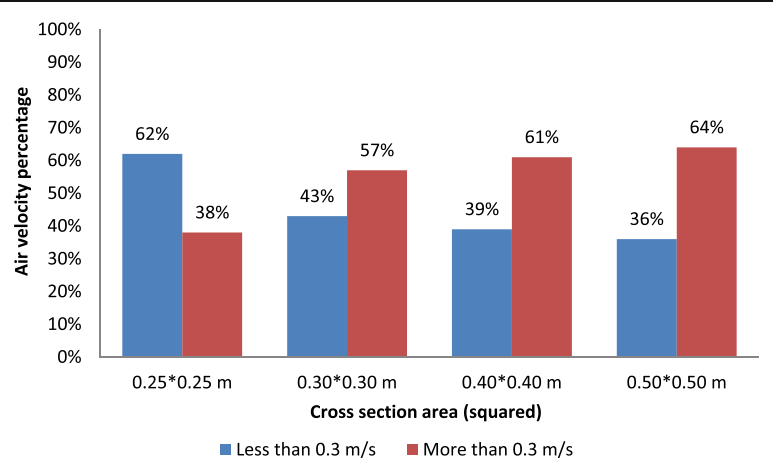

Fig. 11 Percentage of both critical and comfort area to the total area of the tested zone concerning indoor air velocity for cross-section squares at the breathing level zone (1.2 m) (source: the authors)

the entire student density (300 students), and the worst level (e.g., the third floor) in ventilation was chosen to be compared with other levels with halls of similar size and orientations, and it was treated as a general case that can be applied to in this study. In the recent decade, the designers should create ventilation techniques with environmental awareness. Therefore, the chimney is made of glass and the heat absorbent part is darkcolored, and the solar chimney was set to the south direction to increase the air velocity air from 12:00 to 16:00 where the sun rays are oriented southward.

\section{Results and discussion}

The results include the average air velocity values and in comparison to the ASHRAE standard of the minimum: 5 cubic feet per minute (CFM) $(0.3 \mathrm{~m} / \mathrm{s})$, and maximum: 15 cubic feet per minute (CFM) $(0.9 \mathrm{~m} / \mathrm{s})$ through the output contoured results from the CFD

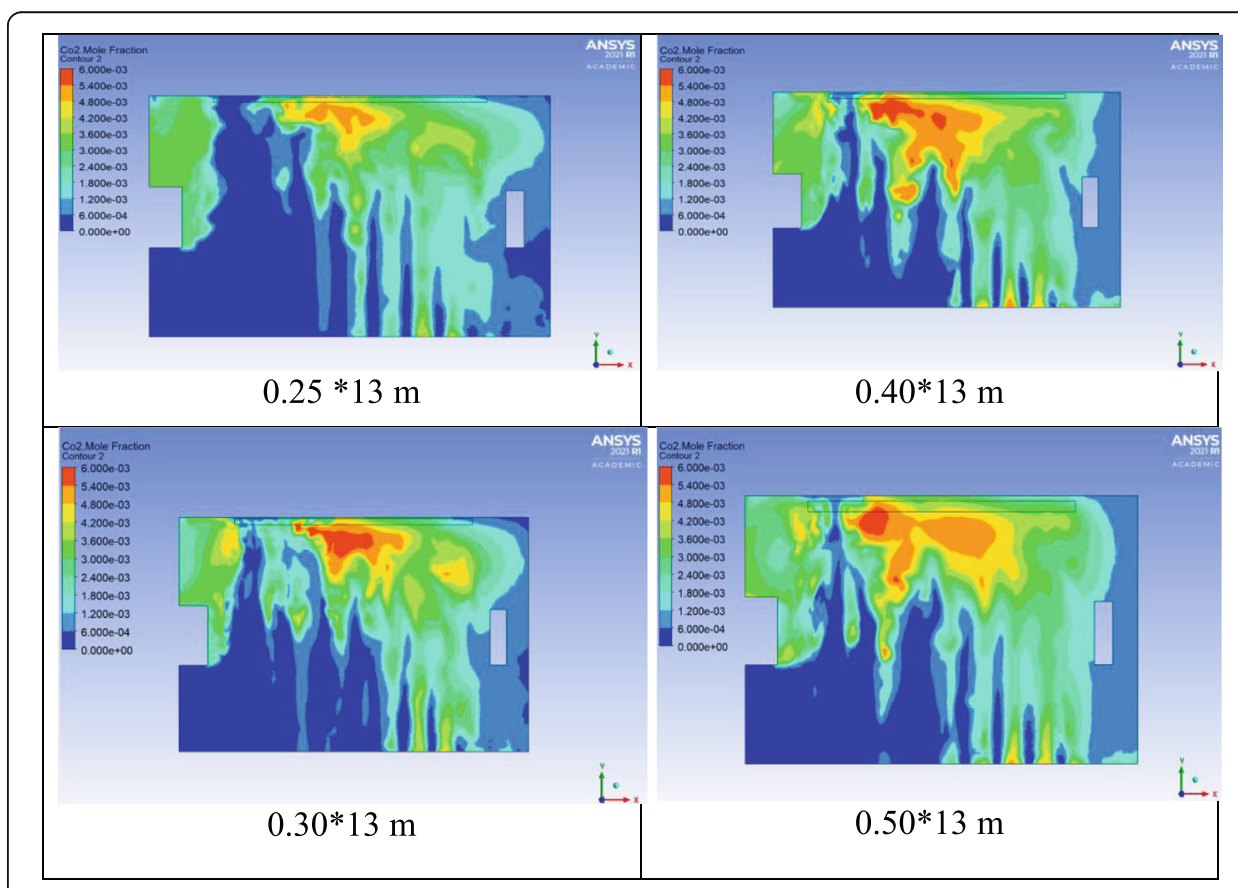

Fig. 12 Contours of $\mathrm{CO}_{2}$ concentrations (ppm) for the rectangular cross-section (wall chimney) at the breathing level zone (1.2 m), output from the ANSYS CFD model (2021R1) 


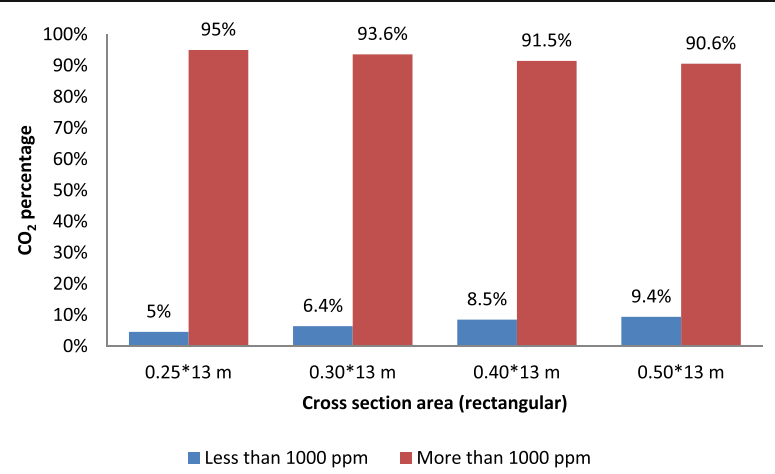

Fig. 13 Percentage of both critical and comfort area to the total area of the tested zone concerning $\mathrm{CO}_{2}$ concentrations (ppm) for the rectangular cross-section at the breathing level zone $(1.2 \mathrm{~m})$ (source: the authors)

model using ANSYS software. The average $\mathrm{CO}_{2}$ concentrations, in comparison to the value of maximum $\mathrm{CO}_{2}$ of the ASHRAE standard level $(1000 \mathrm{ppm})$ inside the lecture's hall together with the design variables of the solar chimney are shown in Fig. 7 and Table 3.

\section{Case one: The squared cross-section}

The effect of the cross-section is tested on the solar chimney squares $(0.25 * 0.25$, $0.30 * 0.30,0.40 * 0.40,0.50 * 0.50 \mathrm{~m})$, which provides the highest performance and is shown in Fig. 8.

The average indoor air velocity was increased to $(38 \%, 57 \%, 61 \%$, and $64 \%$, respectively) causing a significant decrease in the $\mathrm{CO}_{2}$ concentrations to $(3 \%, 6.2 \%, 6.4 \%$, and

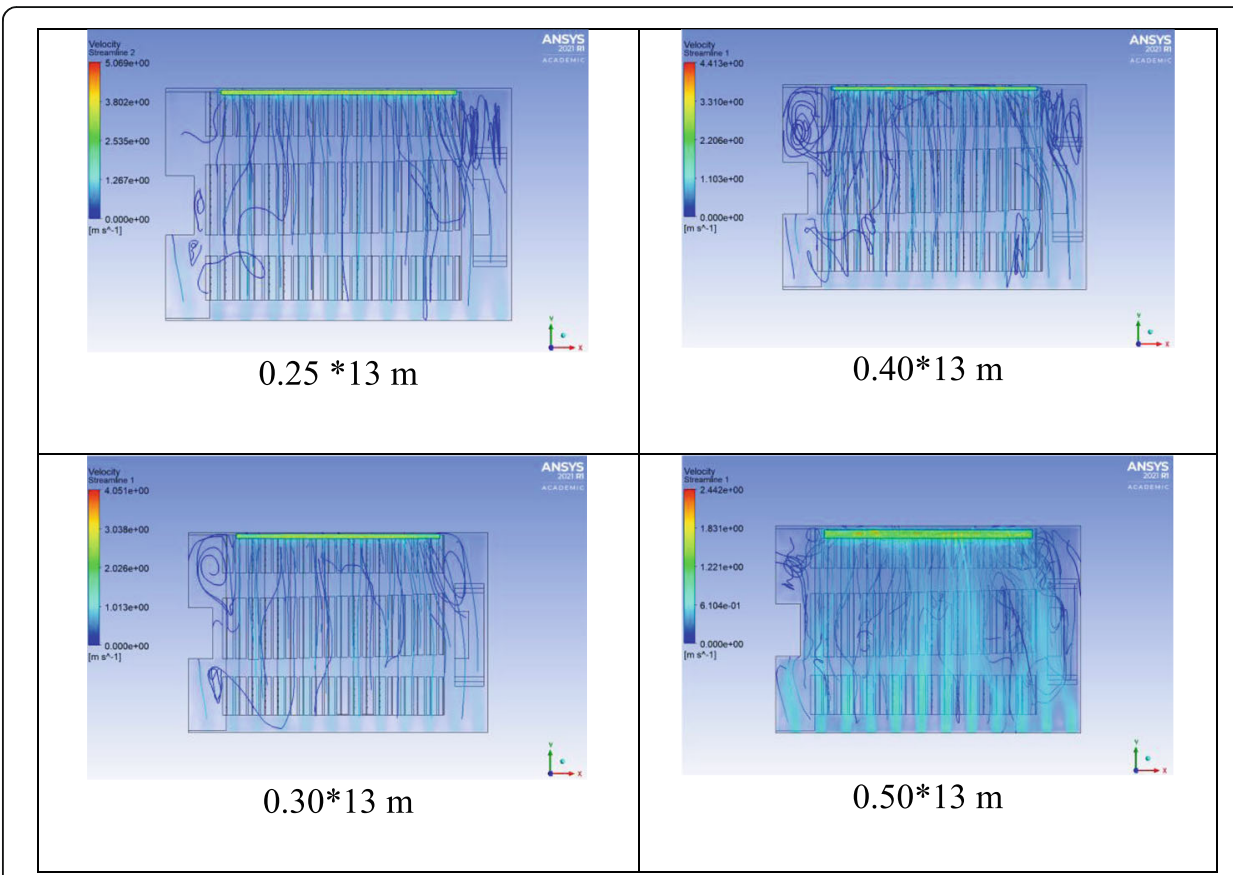

Fig. 14 Stream line air velocity for the rectangular cross-section at the breathing level zone (1.2 m), output from the ANSYS CFD model (2021R1) 


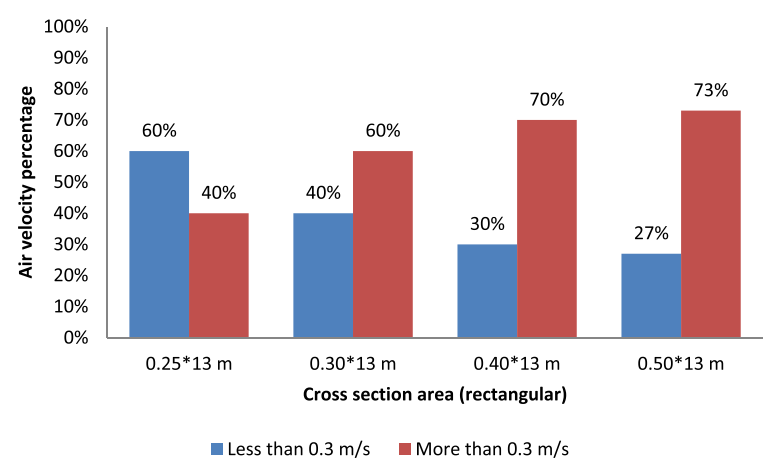

Fig. 15 Percentage of both critical and comfort area to the total area of the tested zone concerning indoor air velocity for the rectangular cross-section at the breathing level zone (1.2 $\mathrm{m}$ ) (source: the authors)

6.7\%, respectively) at the student level (Fig. 8). It is noted that the cross-section $(0.50 * 0.50 \mathrm{~m})$ has the highest improvement $(6.7 \%)$ compared to the ASHRAE standard level $(1,000 \mathrm{ppm})$, while, the rest $93.3 \%$ has an unacceptable level in the lecture's hall (>1000 ppm) (Figs. 8 and 9).

It was observed that the smaller cross-section square $(0.25 * 0.25 \mathrm{~m})$ has an average indoor air velocity (38\%) which is improved to $64 \%$ at $0.50 * 0.50 \mathrm{~m}$ square within the lecture's hall compared to the ASHRAE standards (Figs. 10 and 11). These results are in agreement with those of $[17,32]$.

\section{Case two: The rectangular cross-section}

The effect of different values of the rectangular cross-section (wall chimney) on the indoor air velocity distribution and the $\mathrm{CO}_{2}$ concentrations on the students' breathing level is tested to reach the proper rectangular cross-section which provides the highest ventilation performance and the best air distribution inside a single-facade lecture's hall.

It is observed that the solar chimney's wall increases by increasing the rectangular cross-section. The increasing average indoor air velocity causes a significant decrease in the $\mathrm{CO}_{2}$ concentrations (Figs. 12 and 13). In this case, the $\mathrm{CO}_{2}$ values were improved to $5 \%, 6.4 \%, 8.5 \%$, and $9.4 \%$, respectively, at the wall chimney dimensions $(0.25 * 13$, $0.30 * 13,0.40 * 13$, and $0.50 * 13 \mathrm{~m}$, respectively) (Figs. 12 and 13). Note that the wall

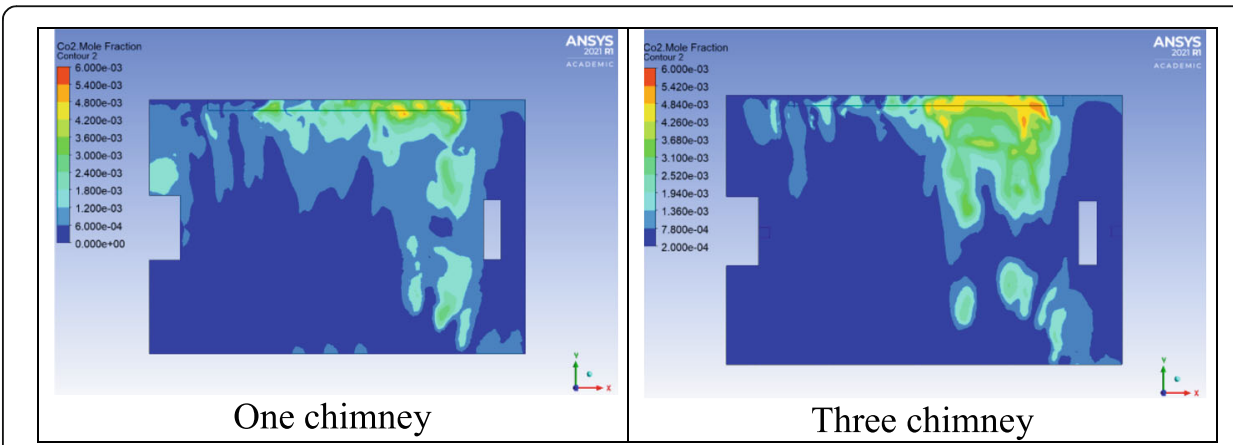

Fig. 16 Contours of $\mathrm{CO}_{2}$ concentration in (ppm) for the number of chimneys at the breathing level zone $1.2 \mathrm{~m}$, output from the ANSYS CFD model (2021R1) 


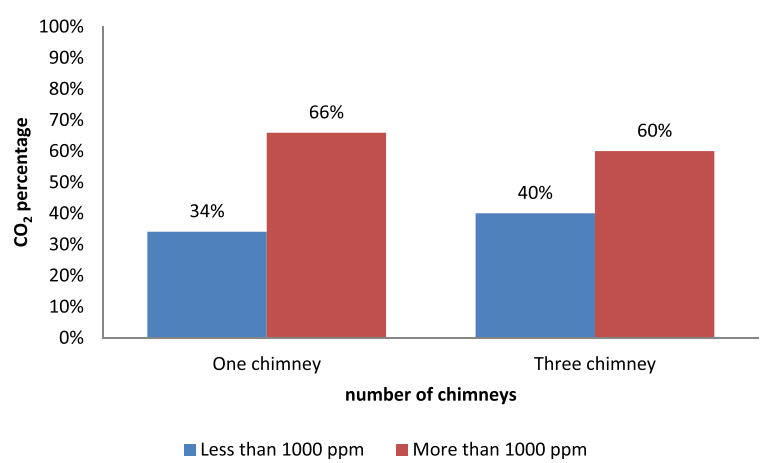

Fig. 17 Percentage of both critical and comfort area to the total area of the tested zone concerning $\mathrm{CO}_{2}$ concentration (ppm) for the number of chimneys at the breathing level zone (1.2 m) (source: the authors)

chimney $(0.50 * 13 \mathrm{~m})$ has the highest performance $(9.4 \%)$ compared to the ASHRAE standard level (Figs. 12 and 13).

The effect of wall chimney on the indoor air velocity was also examined as shown in Fig. 15. It is noted that the proposed $0.25 * 13 \mathrm{~m}$ cross-section area improved the average indoor air velocity by $40 \%$ compared to other wall chimney cross-section areas (Fig. 15 ), and as a result, the $\mathrm{CO}_{2}$ concentrations (ppm) was improved by only $5 \%$ at the student's breathing level inside the single-facade lecture's hall according to the ASHRAE standards (Fig. 13). Based on this, the average indoor air velocity was improved to $(40 \%, 50 \%, 70 \%$, and $73 \%$, respectively) at the wall chimney dimensions $(0.25 * 13,0.30$ * 13, $0.40 * 13$, and $0.50 * 13 \mathrm{~m}$, respectively) (Figs. 14 and 15 ).

\section{Case three: The number of chimneys}

Figure 16 shows the effect of the number of chimneys on the average $\mathrm{CO}_{2}$ concentrations (ppm) inside the lecture's hall, the more number of chimneys, the lecture's hall more ventilated. This means that the air is more mixed and better distributed inside the hall. The number of chimneys, which can be used, depends on the timing which requires reducing the average $\mathrm{CO}_{2}$ concentrations inside the lecture's hall. Using one chimney along the wall has decreased the average $\mathrm{CO}_{2}$ concentrations to $34 \%$, and by using three chimneys the $\mathrm{CO}_{2}$ reduction was up to $40 \%$ (Figs. 16 and 17).

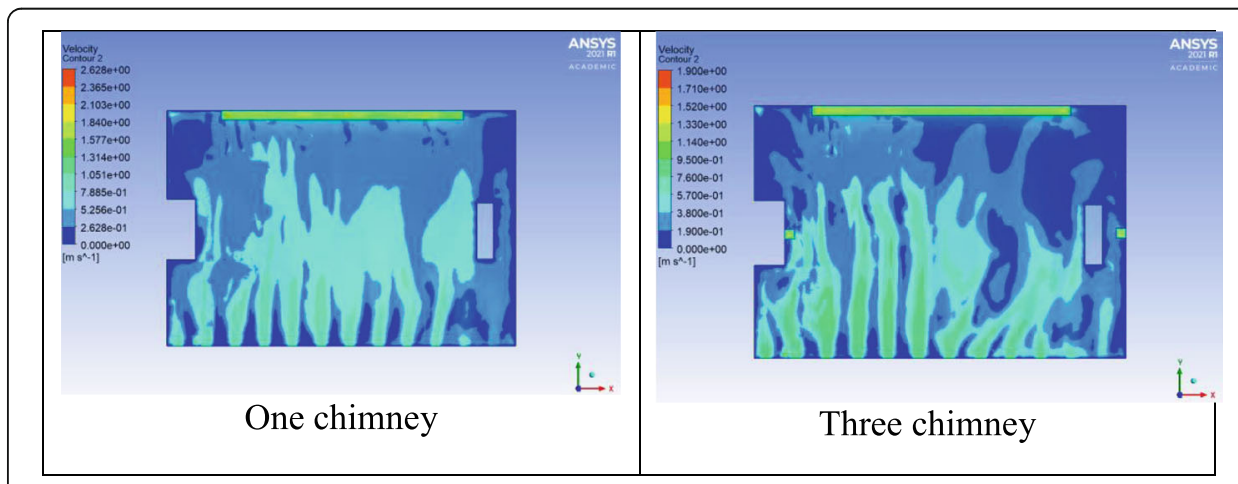

Fig. 18 Contours of air velocity for the number of chimneys at the breathing level zone (1.2 m), output from the ANSYS CFD model (2021R1) 


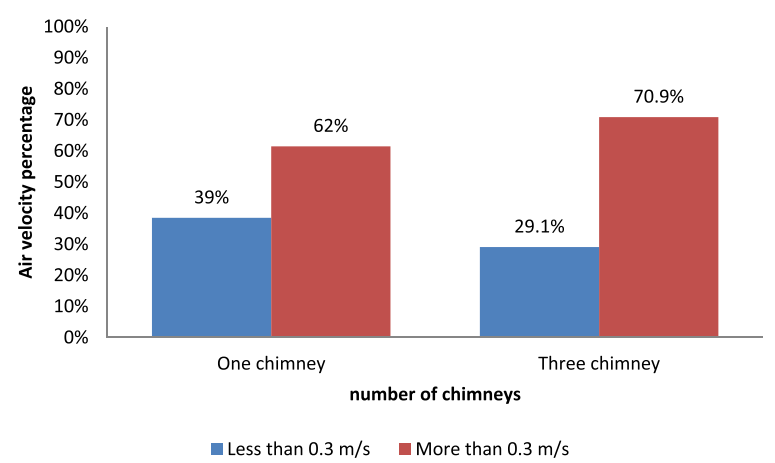

Fig. 19 Percentage of both critical and comfort area to the total area of the tested zone concerning indoor air velocity for the number of chimneys at the breathing level zone (1.2 $\mathrm{m}$ ) (source: the authors)

Note that the use of multiple solar chimneys can increase the ventilation flow rate inside the lecture's hall by using multiple stacks (Fig. 18). Accordingly, it was noticed that in one chimney, the ventilation flow rate reaches $61 \%$, and increasing the number of chimneys to three can increase the ventilation flow rate to $70.9 \%$ (Fig. 19). These results are much higher than $13-33 \%$ of [17].

\section{Case four: The chimney's height $(1,3,5$, and $7 \mathrm{~m})$.}

Figure 20 shows the height of the chimney and its effect on the average $\mathrm{CO}_{2}$ concentrations for the solar chimneys. When the chimney's heights are more facing the lecture's hall surface, it can be a negative pressure zone toward the sun direction (to the south in this case). The more the chimney's height is, the more the chimney's temperature

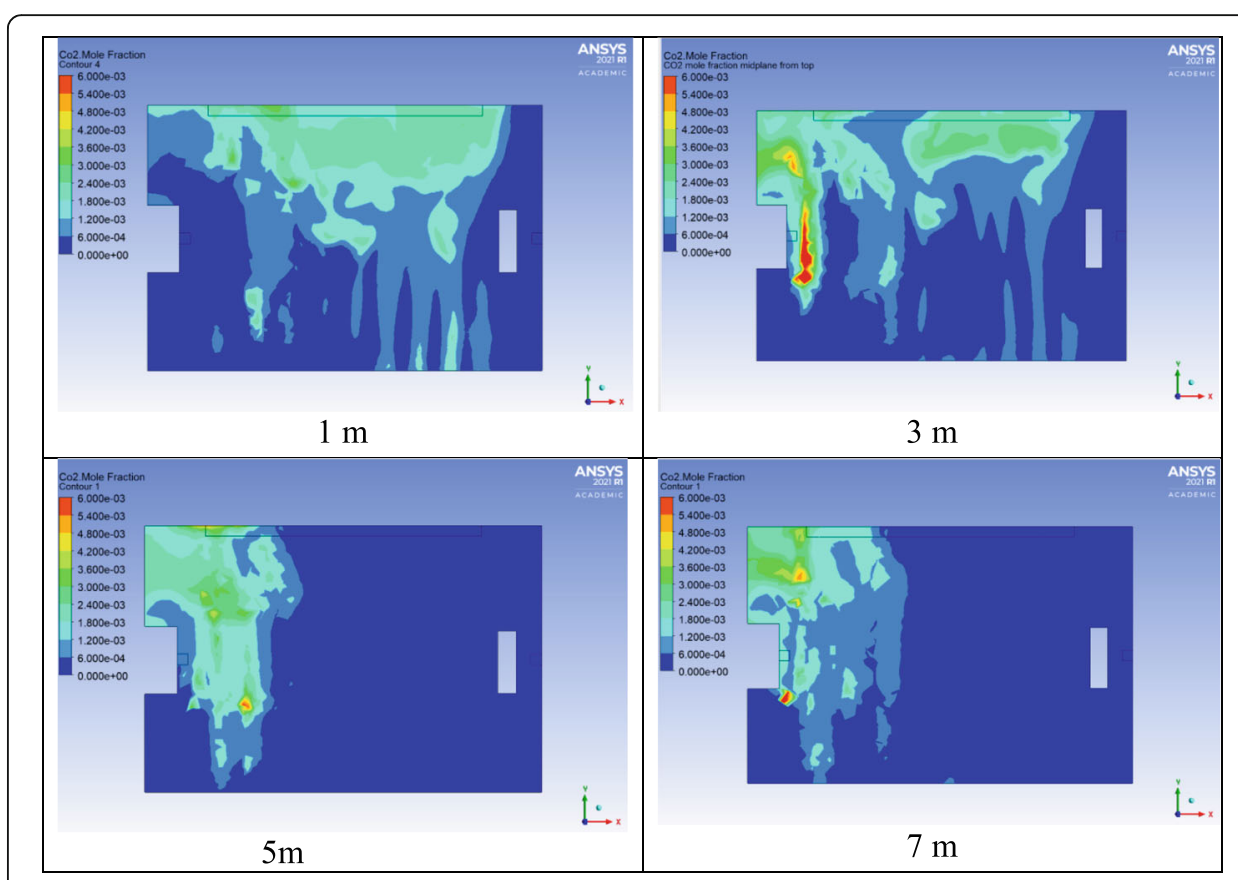

Fig. 20 Contours of $\mathrm{CO}_{2}$ concentration (ppm) at different heights of the chimney at the breathing level of students $1.20 \mathrm{~m}$, output from the ANSYS CFD model (2021R1) 


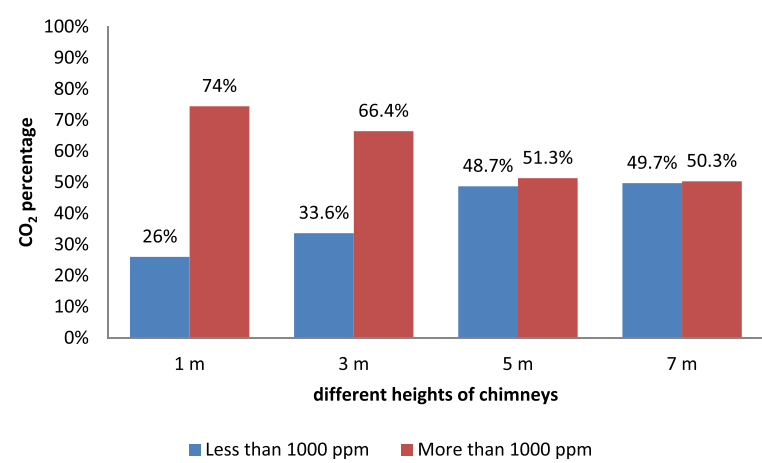

Fig. 21 Percentage of both critical and comfort area to the total area of the tested zone concerning $\mathrm{CO}_{2}$ concentration in (ppm) for the different heights of chimneys at the breathing level zone $1.20 \mathrm{~m}$ (source: the authors)

increases. This can be attributed to the thermal energy gained through the air as it passes through the chimney (Fig. 20).

The effect of the chimney's height on the average $\mathrm{CO}_{2}$ value inside the lecture hall was improved at the different chimney's heights $(1,3,5$, and $7 \mathrm{~m}$, respectively) to $26 \%$, $33.6 \%, 48.7 \%$, and $49.7 \%$, respectively (Fig. 21 ).

It is noted that the chimney's height of $5 \mathrm{~m}$ was the most proper because it is located in the air comfort area of the students and it should not exceed 15 CFM $(0.9 \mathrm{~m} / \mathrm{s})$ per person, while the height $7 \mathrm{~m}$ was excluded because it exceeds the recommended ASHRAE standards (Figs. 22 and 23). The average indoor air velocity was improved to (33\%, $70.9 \%, 74.2 \%$, and $89.6 \%$, respectively) at the wall chimney heights $(1,3,5$, and $7 \mathrm{~m}$, respectively) (Figs. 22 and 23). These results are in agreement with similar trends of [17].

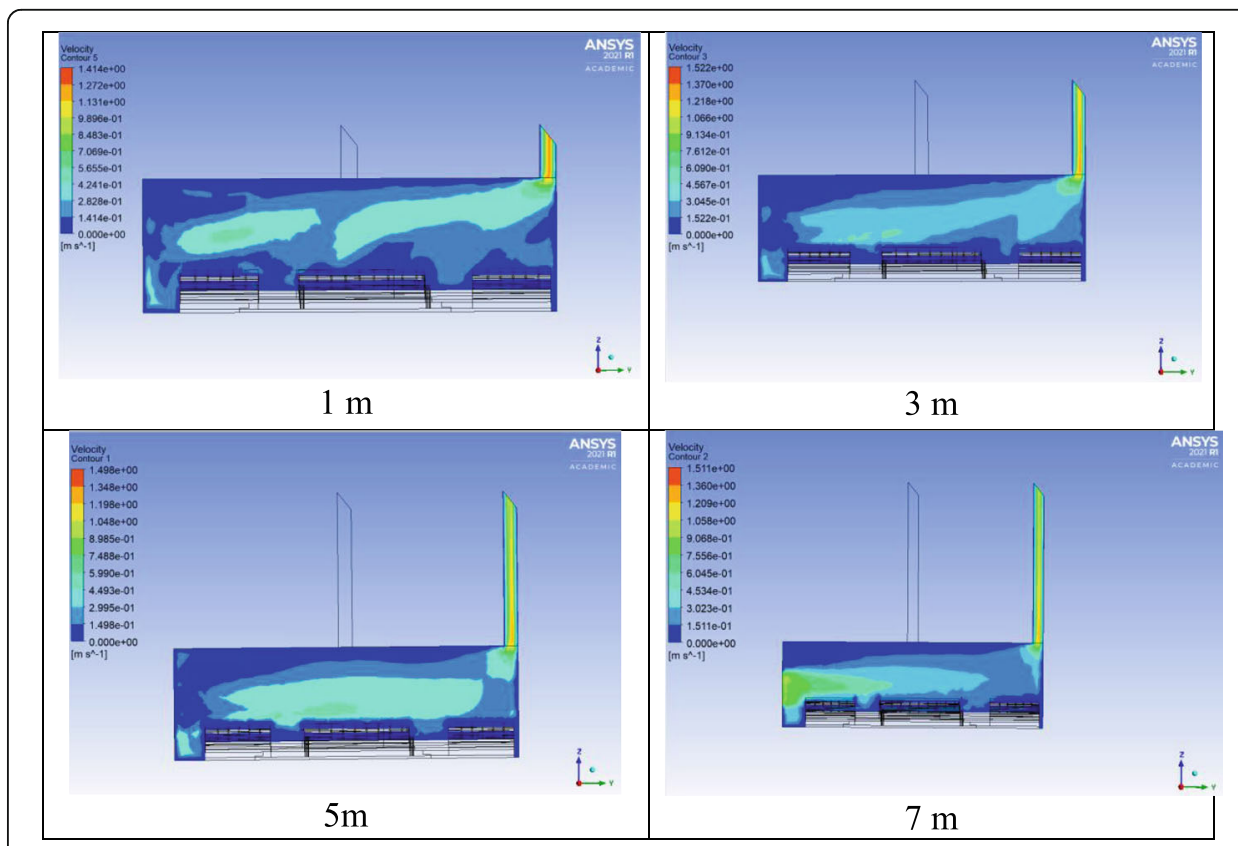

Fig. 22 Contours of air velocity at different heights of the chimney at the breathing level of students 1.20 m, output from the ANSYS CFD model (2021R1) 


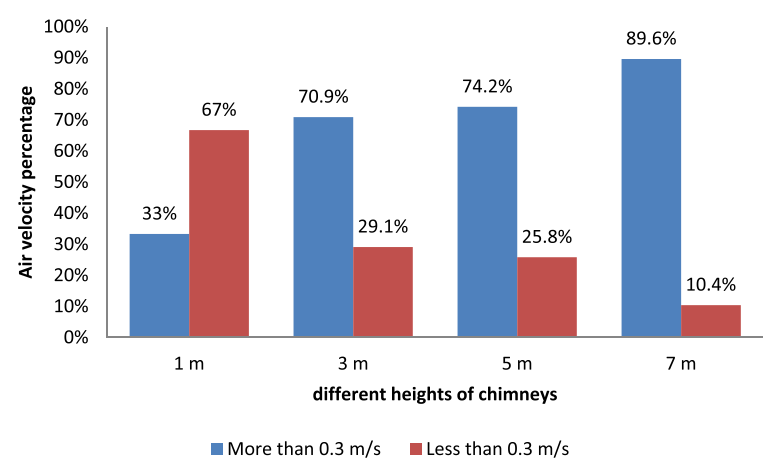

Fig. 23 Percentage of both critical and comfort area to the total area of the tested zone concerning indoor air velocity for different heights of the chimney at the breathing level zone $1.2 \mathrm{~m}$ (source: the authors)

The adopted methodology in this paper has its limitations such as the measured data were carried out in a single-façade, large-size hall, with natural ventilation, located in a square with high traffic density on October 2017 (fall season) which is the beginning of the first semester with low air masses entering the hall. However, other studies were focused on small classroom [30] and small residential rooms [31]. These limitations should be overcome in any future research studies. Additionally, the authors recommend conducting a future research on halls in the coastal areas, in variable seasons (summer, winter, and spring) and focusing on the effect of adequate ventilation systems on reducing other pollutants such as dust, fungi, bacteria, viruses, and VOCs through periodical measurements.

\section{Conclusions}

A field study in a naturally ventilated, single-faceted lecture's hall at the Faculty of Engineering, Cairo University, was investigated to evaluate the indoor air quality (IAQ). The air velocity and $\mathrm{CO}_{2}$ concentrations were measured at the student's breathing level and the results were compared with the ASHRAE standards. Numerical 3D CFD modeling was applied on the measured data using ANSYS Fluent software. The CFD model was validated, and the deviation between the numerical and measured results has an average of $6.2 \%$, which has a fair agreement with literature. The fresh air was insufficient and poorly distributed in the studied lecture's hall. Accordingly, the hall was polluted with $\mathrm{CO}_{2}$ concentrations higher than the ASHRAE standard. In addition, the number of students was an effective parameter in this study up to the maximum capacity of 300 students that give higher $\mathrm{CO}_{2}$ concentrations. On the other hand, the solar chimney worked to move the air inside the hall and significantly reduced the average $\mathrm{CO}_{2}$ concentrations inside the hall through the proper cross-sectional area of $0.50^{*} 13 \mathrm{~m}$. The multiple solar chimneys helped to distribute the air inside the hall in an acceptable manner and using three chimneys delivered the best performance. Similarly, the chimney height of 5 $\mathrm{m}$ on the air flow rate gave the best performance. It is noted that there are few studies investigating the IAQ role in the lecture's halls in the developing countries compared to those in the developed world, which can be referred to the limited resources and logistic issues. 
Abbreviations

ASHRAE: American Society of Heating, Refrigerating and Air-Conditioning Engineers; ACH: Air changes per hour; CFD: Computational Fluid Dynamics; CFM: Cubic feet per minute; $\mathrm{CO}_{2}$ : Carbon dioxide

\section{Acknowledgements}

Not applicable.

\section{Authors' contributions}

AF reviewed and proposed the values for chimney design specifications. AE conducted the numerical and measured modeling and wrote the manuscript. Both authors read and approved the final manuscript.

\section{Funding}

This study had no funding from any resource.

\section{Availability of data and materials}

All data and materials will be available upon request.

\section{Declaration}

\section{Competing interests}

The authors declare that they have no competing interests.

\section{Author details}

${ }^{1}$ Environmental Architecture Department, Faculty of Engineering, Cairo University, Giza, Egypt. ${ }^{2}$ Architecture

Department, Giza Higher Institute of Engineering and Technology, Giza, Egypt.

Received: 6 May 2021 Accepted: 4 October 2021

Published online: 17 November 2021

\section{References}

1. WHO (2010) Guidelines for indoor air quality: selected pollutants. WHO Regional Office for Europe publications, World Health Organization (WHO) https://www.euro.who.int/_data/assets/pdf_file/0009/128169/e94535.pdf

2. WHO (2000) WHO Air Quality Guidelines for Europe, 2nd edn. World Health Organization Regional Publication, European Series No. 91, Copenhagen https://www.euro.who.int/

3. Aizlewood C, Dimitroupoulou C (2006) The HOPE project: the UK experience. Indoor Built Environ 15(5):393-409 https:// journals.sagepub.com/

4. Kasuga H (ed) (1990) Indoor Air Quality, Library of Congress Cataloging-in-Publication Data. Springer-Verlag, Berlin Heidelberg

5. Abdullah S, Ismail M, Najah A (2019) Data on Indoor Air Quality (IAQ) in kindergartens with different surrounding activities. Data Brief 25:103969. https://doi.org/10.1016/j.dib.2019.103969

6. Elshahat A, Soliman AA, Elshahat MF (2019) Studying the effect of the fuel used on the pollutants emission from the power plants west Cairo. Life Sci J 16(4) http://www.lifesciencesite.com/

7. Aziz NA, Husain RN (2018) Indoor air quality in a Northeast Coast Malaysian Medical School. Environment Asia 11(2):6779. http://www.tshe.org/ea/pdf/EA11(2)_06.pdf

8. Williams MJ, Awbi HB, Clements-Croome DJ, Bakó-Biró Z (2008) Ventilation rates in schools. Building Environ 43(3):362-367

9. Sulaiman MA, Zahari WU, Kamarudin WN, Pawi S (2013) Indoor Environmental Quality (IEQ) of Higher Education Institutions (HEls): a user perception survey. J Clean Energy Technol 1(72):318-321. https://doi.org/10.7763/JOCET.2 013.V1.72

10. USEPA (2010) Buildings codes and indoor air quality. US Environmental Protection agency (EPA), Arlington

11. Eichholtz P, Kok N (2018) Indoor environmental quality and human performance: evidence from a large-scale field study. Maastricht University https://sustainable-finance.nl/upload/researches/Eichholtz-et-al-Indoor-Air-Qualityin-Schools.pdf

12. Stonier RT (1995) $\mathrm{CO}_{2}$ : powerful IAQ diagnostic tool. Heating. Piping Air Conditioning 67(3), USA

13. Abdeen SA, Bady M, Ookawara S, Abdel-Rahman AK (2016) Achieving standard natural ventilation rate of dwellings in a hot-arid climate using solar chimney. Energy Build 133:360-370. https://doi.org/10.1016/j.enbuild.2016.10.001

14. Al-Kayiem HH, Sreejaya KV, Gilani SIU-H (2014) Mathematical analysis of the influence of the chimney height and collector area on the performance of a roof top solar chimney. Energy Build 68:305-311. https://ahmadliaghat.ir/. https://doi.org/10.1016/j.enbuild.2013.09.021

15. Hashim HS, Kassim MS, Kadhim HH (2020) Numerical investigation for natural ventilation enhancement in different models of solar chimney inside a room elicited from the concepts of the conventional chimney model. J Mech Eng Re Dev 43(5):436-450

16. Lin Z, Chow TT, Tsang CF, Fong KF, Chan LS (2004) CFD study on effect of the air supply location on the performance of the displacement ventilation system. Building Environ 40(8):1051-1067

17. Hassanein SA, Waleed AA (2012) Improvement of natural ventilation in building using multi solar chimneys at different directions. J Eng Sci Assiut Univ 40(6):1661-1677

18. Abdeen A, Serageldine AA, Ibrahim MGE, El-Zafarany A (2019) Solar chimney optimization for enhancing thermal comfort in Egypt: an experimental and numerical study. Solar Energy 180:524-536. https://doi.org/10.1016/j.solener.2019.01.063

19. Cheong KWD, Djunaedy E, Chua YL, Tham KW, Sekhar SC, Wong NH, Ullah MB (2003) Thermal comfort study of an airconditioned lecture theatre in the tropics. Building Environ 38(1):63-73. https://doi.org/10.1016/S0360-1323(02)00020-3

20. Awbi HB, Gan G (1994) Predicting air flow and thermal comfort in offices. ASHRAE J 36(2):17-21 
21. Cheong KWD, Sekhar SC, Tham KW, Djunaedy E (1999) Airflow pattern in air conditioned seminar room. Indoor Air 99. Proc Eighth Intern Conference Indoor Air Quality Climate 2:54-59 https://www.aivc.org/sites/default/files/members_a rea/medias/pdf/Conf/1999/paper052.pdf

22. Hviid CA, Knudsen HN, Markvart J (2018) A comparative study of the indoor environmental quality in renovated and non-renovated classrooms. Proceedings-Roomvent \&Ventilation, Aalto University, Espoo, Finland. https://www. gate21.dk/.

23. Jiang QW, Meng XZ, Liu YH, Chen JB, Zhao M (2018) Measurement and Evaluation on Air Quality of the University Library with HVAC System. 4th International Conference on Building Energy \& Environment (cobee2018), Melbourne http://www.cobee2018.net/assets/pdf/p/246.pdf

24. Karami M (2018) Continuous monitoring of indoor environmental quality using an Arduino-based data acquisition system. J Building Eng 19:412-419. https://doi.org/10.1016/j.jobe.2018.05.014

25. ASHRAE (2019) ASHRAE Standard 62.1 ventilation for acceptable indoor air quality. American Society of Heating, Refrigerating and Air Conditioning Engineers, Atlanta https://aws.state.ak.us/OnlinePublicNotices/Notices/Attachment.a spx?id=113385

26. Ansys ${ }^{\circledast}$ Academic Research Mechanical software, Release 2021 R1, Help System, Coupled Field Analysis Guide, ANSYS, Inc. https://www.ansys.com/products/release-highlights.

27. Guyton AC (1986) Textbook of medical physiology (7th ed.), Saunders College Publishing/Harcourt Brace

28. Schottelius BA (1978) Textbook of physiology, Philadelphia

29. Egyptian Code for Ventilation in Building (2017) National Research Centre (NRC).

30. Fouad MA, Sayed A (2012) Experimental and numerical indoor air quality study in naturally ventilated campus classroom in Egypt. Faculty of Engineering- Mataria Engineering research journal 134(June 2012) M11-M25

31. Samy R, Reda A, Sayed IA (2016) Improving natural ventilation design for spaces with single-sided ventilation using computational fluid dynamics. PhD Thesis, Faculty of Engineering, Cairo University

32. Amori KE, Mohammed SW (2012) Experimental and numerical studies of solar chimney for natural ventilation in Iraq. Energy Building 47:450-457. https://doi.org/10.1016/j.enbuild.2011.12.014

\section{Publisher's Note}

Springer Nature remains neutral with regard to jurisdictional claims in published maps and institutional affiliations.

\section{Submit your manuscript to a SpringerOpen ${ }^{\circ}$ journal and benefit from:}

- Convenient online submission

- Rigorous peer review

- Open access: articles freely available online

- High visibility within the field

- Retaining the copyright to your article

Submit your next manuscript at $\boldsymbol{\nabla}$ springeropen.com 